\title{
MENDIALOGKAN NALAR AGAMA DAN SAINS MODERN DI TENGAH PANDEMI COVID-19*
}

\author{
M. Amin Abdullah \\ $\overline{\text { UIN Sunan Kaljaga, Yogyakarta }}$ \\ aminabdullah53@gmail.com
}

\section{Abstrak}

Hubungan agama dan ilmu menurut Ian G. Barbour dapat diklasifikasi menjadi empat corak, yaitu, Konflik, Independen, Dialog dan Integrasi. Apa implikasi dan konsekwensi dari paradigma Dialog dan Integrasi jika diterapkan dalam keilmuan agama, khususnya agama Islam, melalui perspektif pemikir Muslim kontemporer. Hal ini penting karena praktik pendidikan dan dakwah agama pada umumnya masih menggunakan paradigma Konflik dan Independensi. Baik yang menggunakan paradigma Konflik dan atau Independen maupun paradigma Dialog dan Integrasi akan besar berpengaruh pada pembentukan budaya berpikir sosial-keagamaan baik di ruang privat maupun publik. Argumen yang hendak diajukan adalah bahwasanya hubungan antara agama, dalam hal ini 'Ulumu al-din (ilmu-ilmu agama Islam) dan ilmu, baik ilmu kealaman, sosial maupun budaya meniscayakan corak hubungan yang bersifat dialogis, integratif-interkonektif. Hubungan antara disiplin ilmu keagamaan dan disiplin ilmu alam, sosial dan budaya di era modern dan post-modern adalah bersifat semipermeable, intersubjective testability dan creative imagination. Studi Keislaman (Dirasat Islamiyyah) kontemporer memerlukan pendekatan multidisiplin, interdisiplin dan transdisiplin. Linearitas ilmu dan pendekatan monodisiplin dalam rumpun ilmu-ilmu agama akan mengakibatkan pemahaman dan penafsiran agama kehilangan kontak dengan realitas dan relevansi dengan kehidupan sekitar. Budaya berpikir baru yang secara mandiri mampu mendialogkan sisi subjective, objective dan intersubjective dari ilmu dan agama menjadi niscaya dalam kehidupan multireligi-multikultural dan terlebih di era multikrisis yang melibatkan sains, kesehatan, sosial, budaya, agama, politik, ekonomi, keuangan sekaligus akibat penyebaran pandemi Covid-19 di dunia

\footnotetext{
* Tulisan ini adalah pengembangan lebih lanjut dari tulisan saya yang berjudul "Agama, Ilmu dan Budaya”, tahun 2013. Versi Pdf dapat diakses pada https://aminabd.files.wordpress.com/2013/10/agama-ilmu-dan Budaya.pdf.

Versi bahasa Inggris dapat diakses di https://www.aljamiah.or.id/index.php/AJIS/article/view/52108
} 
sekarang ini. Kesemuanya ini akan mengantarkan perlunya upaya yang lebih sungguh-sungguh dan ketekunan untuk melakukan rekonstruksi metodologi studi keilmuan dan metodologi studi keagamaan di tanah air sejak dari hulu, yakni filsafat ilmu dan filsafat ilmu-ilmu keislaman sampai ke hilir, yaitu proses dan implementasinya dalam praksis pendidikan dan dakwah keagamaan.

Kata kunci: Konflik-Independen-Dialog-Integrasi; Semipermeable;

Intersubjective Testability; Creative Imagination; Muslim

Progressif; Fresh Ijtihad.

\section{Pendahuluan}

Dari wabah ke wabah ${ }^{1}$, dari krisis ke krisis adalah agenda umum yang selalu dihadapi kehidupan umat manusia. Belum lama bangsa Indonesia telah berhasil melewati tahapan paling sulit, hampir memasuki krisis, jika tidak teratasi dengan baik dalam menjalani demokrasi, yaitu penyelenggaraan pemilihan presiden tahun 2019 dengan seluruh rangkaian peristiwa yang menyertainya, Disebut hampir masuk ke tahapan krisis karena benturan yang cukup keras antara pemahaman dan penafsiran agama tertentu yang dibawa-bawa masuk ke arena politik berhadapan dengan pandangan politik yang berseberangan. Berita bohong (fake news), berita palsu (hoax), kampanye hitam dan kampanye negatif menggoncang kestabilan dan harmoni kehidupan sosial dan utamanya psikologi sosial keagamaan di tanah air. Bangsa Indonesia bersyukur dapat menyelesaikan dan melewati babak paling sulit dalam menegakkan ritual demokrasi politik di tanah air. Ternyata daya tahan bangsa Indonesia dalam menghadapi krisis politik telah cukup teruji sejak dari peralihan kepemimpinan negara dari orde lama ke orde baru, dari orde baru ke orde reformasi.

Tibalah sekarang krisis baru yang lebih dahsyat dengan daya rusak yang mematikan karena berskala global. Penyebaran virus Covid-19 semula ditengarai menyebar pertama di Wuhan, Cina pada Desember 2019 dan dalam waktu singkat menyebar ke Korea Selatan, Iran, Italia, Spanyol, Amerika Serikat, Perancis, Inggris dan seluruh negara dunia tidak terkecuali Indonesia. Krisis

$1 \quad$ Belum lama Indonesia terserang wabah SARS tahun 2003 dan wabah flu burung, tahun 2012. Tidak hanya wabahnya yang menghebohkan dunia, tetapi juga tarik ulur pengambilan sampel flu burung untuk penelitian laboratorium pembuatan vaksin. Tahun 1918 dunia juga terkena wabah yang lebih dahsyat sehingga memakan korban sekitar 20 sampai 50 juta orang. Diperkirakan penduduk dunia saat itu 3 milyar jiwa. Sekarang tahun 2020, dunia terserang pandemi Covid-19. Artinya, wabah penyakit selalu timbul tenggelam setiap kurun waktu tertentu. Lebih lanjut bagaimana pandemi yang terjadi tahun $1918 \mathrm{di}$ Hindia Belanda, lihat Priyanto Wibowo dkk., Yang Terlupakan Pandemi Influenza 1918 di Hindia Belanda, Depok: Kerjasama antara Departemen Sejarah Fakultas IImu Pengetahuan Budaya, Universitas Indonesia, Unicef Jakarta dan Komnas FBPI, 2009. 
di bidang kesehatan (penyebaran virus yang tidak terbendung) yang secara cepat merembet melibatkan multiaspek kehidupan, baik sosial, budaya, agama, ekonomi, politik, finansial bahkan pendidikan. Dikhawatirkan, jika tidak tertangani dengan serius secara keilmuan dan kerjasama manusia secara global akan berimbas pada resesi ekonomi dunia. Pemerintah Indonesia akhirnya pada bulan April 2020 mengeluarkan peraturan Pembatasan Sosial Berskala Besar (PSBB) yang bertujuan untuk mencegah kerumunan orang banyak karena kerumunan disebut sebagai salah satu sumber penyebaran virus Korona yang eksponensial. PSBB menganjurkan untuk Tinggal di Rumah (Stay at Home), Kerja di Rumah (Work at Home), dan Ibadah di Rumah (Pray at Home), selain rajin mencuci tangan yang benar, menggunakan masker, cara bersin atau batuk yang benar, menjaga daya tahan tubuh dan seterusnya. Kebijakan pemerintah tentang PSBB diambil dari inti sari ilmu pengetahuan khususnya ilmu kesehatan, kedokteran dan farmasi maupun ilmu-ilmu sosial-budaya, baik bersumber dari Kementerian Kesehatan, Ikatan Dokter Indonesia (IDI) maupun dari organisasi kesehatan dunia di bawah Persatuan Bangsa-Bangsa (PBB), World Health Organization (WHO).

Peraturan pemerintah yang dipandu oleh prinsip-prinsip keilmuan dan pengalaman dunia internasional tersebut ada yang bersentuhan dan bertabrakan langsung dengan basis ajaran, kepercayaan dan keimanan agama dan aturan peribadatan umat beragama pada umumnya, khususnya salat berjamaah di masjid bagi umat Islam atau misa dan kebaktian di gereja bagi umat Kristiani dan sinagog bagi Yahudi. Ibadah umrah di Makkah dan ziarah di Madinah telah ditutup oleh pemerintah Saudi Arabia. Begitu juga agama-agama yang lain. Bagi pengikut ajaran agama yang keras dari semua agama menganggap bahwa virus Korona umumnya dianggap sebagai kutukan Tuhan bagi manusia yang tidak lagi mengenal Tuhan atau tatanan kehidupan yang tidak lagi mengikuti dan mengindahkan ajaran-ajaran agama. Avatar bagi kaum non-vegetarian dalam agama Hindu. Menurut mereka, orang yang beriman pasti imun dari wabah virus Korona karena diselamatkan oleh Allah, diselamatkan oleh darah Yesus².

Semangat membara dalam beragama rupanya dapat berimplikasi terhadap penomorduaan dan ketidakpedulian terhadap kesehatan dan keselamatan manusia yang lebih luas. Terlebih lagi, akan terasa dampak dari peraturan pemerintah bagi umat Islam yang akan menjalani ibadah puasa ramadan, salat tarawih di masjid-masjid dan mushalla serta salat idul fitri di masjid maupun

2. Adrianus Suyadi, “Peran Agama Hadapi Covid -19”, Kompas, 26 Maret 2020, h. 6. Azyumardi Azra, "Virus Korona; Splinter Agama", Republika, 2 April 2020, h. 7. Juga Zacky Khairul Umam, "Korona, Antara Sains dan Agama", Kompas, 10 Maret 2020, h.7. 
di lapangan terbuka. Sudah barang tentu timbul respons dan reaksi dari umat beragama khususnya Islam karena rangkaian ibadah puasa ramadan umumnya melibatkan kerumunan masa yang cukup besar. Jika dibuat jarak antara 1 sampai 2 meter antara berdirinya jamaah yang satu dan lainnya dalam salat berjamaah tetap saja tidak dapat menghindari kerumunan ketika berwudlu, ketika di jalan dan ketika mau masuk masjid dan begitu seterusnya. Untuk dicatat bahwa persoalan yang sama juga dialami oleh pengikut agama-agama lain di dunia. Dari itu, muncul pertanyaan bagaimana sesungguhnya hubungan antara "agama" dan "ilmu", antara religion and science khususnya dalam menghadapi krisis kesehatan? Mengapa pada saat-saat tertentu terjadi ketegangan hubungan antara keduanya? Bagaimana hubungan yang ideal antara keduanya? Apa yang perlu diperbaiki dan dikembangkan dalam dunia pendidikan dimasa depan?

\section{Integrasi-Interkoneksi (I-Kon) Keilmuan.}

Sebagaimana dipaparkan Ian G. Barbour, setidaknya, ada 4 pola hubungan antara agama dan ilmu, yaitu Konflik (bertentangan), Independen (masingmasing berdiri sendiri-sendiri), Dialog (berkomunikasi) atau Integrasi (menyatu dan bersinergi). Hubungan yang bercorak Konflik dan atau Independen tidak nyaman untuk menjalani kehidupan yang semakin kompleks. Banyak lobanglobang yang menjebak, penuh resiko, jika pilihan hubungan antara agama dan ilmu adalah Konflik dan atau Independen. Idealnya hubungan antara keduanya adalah Dialog dan jauh lebih baik jika dapat berbentuk Integrasi. Secara teoritik, dengan mengambil inspirasi dari Ian G. Barbour dan Holmes Rolston, III, juga Abdolkarim Soroush, Nidhal Guessoum dan Jasser Auda, ada 3 kata kunci yang menggambarkan hubungan agama dan ilmu yang bercorak Dialogis dan Integratif, yaitu Semipermeable, Intersubjective Testability dan Creative Imagination.

\section{Saling Menembus}

Konsep Semipermeable (saling menembus) ini berasal dari keilmuan biologi. Dalam biologi, kaedah Survival for the fittest (Makhluk dapat bertahan hidup adalah yang paling cepat dapat menyesuaikan diri) adalah yang paling menonjol. Hubungan antara ilmu yang berbasis pada "kausalitas" (Causality; pecarian hukum sebab dan musabab) dan agama yang berbasis pada "makna" dan nilai (Meaning; value) adalah bercorak semipermeable, yakni, antara keduanya saling menembus. Mengapa timbul konflik antara penafsiran agama dan penafsiran ilmu pengetahuan terhadap realitas karena hubungan antara keduanya tidak saling menembus, tidak saling berkomunikasi. Masing-masing 
menganggap bahwa tafsir disiplin keilmuannya sendiri lah yang paling benar dan menganggap tafsir yang lain tidak benar. Beda posisi yang tajam inilah yang menimbulkan konflik yang tidak bisa didamaikan (The conflicts between scientific and religious interpretations arise because the boundary between causality and meaning is semipermeable). ${ }^{3}$ Hubungan antara ilmu dan agama semestinya tidaklah dibatasi oleh pagar, tembok atau dinding tebal yang tidak memungkinkan untuk berhubungan dan berkomunikasi, tersekat atau terpisah sedemikian ketat dan rigidnya, melainkan saling menembus, saling merembes, saling berkomunikasi. Saling menembus secara sebagian, dan bukannya secara bebas dan total. Masih tampak garis batas demarkasi antar bidang disiplin ilmu, namun ilmuan antar berbagai disiplin tersebut saling membuka diri untuk berkomunikasi dan saling menerima masukan dari disiplin di luar bidangnya. Hubungan saling menembus ini dapat bercorak klarifikatif, komplementatif, afirmatif, korektif, verifikatif maupun transformatif.

Dalam menggambarkan proses transformasi akademik dari Institut Agama Islam Negeri (IAIN) ke Universitas Islam Negeri (UIN) tahun 2003/2004, telah dilukiskan pola hubungan antar disiplin keilmuan keagamaan dan keilmuan non-keagamaan secara metaforis mirip-mirip dengan "jaring laba-laba keilmuan" (Spider web) yang menggambarkan adanya jaringan atau networking keilmuan. Antar berbagai disiplin ilmu yang berbeda tersebut saling berhubungan dan berinteraksi secara aktif-dinamis. Hubungan antar berbagai disiplin dan metode keilmuan tersebut bercorak integratif-interkonektif. ${ }^{4}$ Yang jarang terbaca atau luput dari pengamatan sekilas ketika melihat gambar metaporis "jaring labalaba keilmuan” itu adalah adanya garis putus-putus, menyerupai pori-pori yang melekat pada dinding pembatas antar berbagai disiplin keilmuan tersebut. Dinding pembatas yang berpori-pori tersebut tidak saja dimaknai dari segi batas-batas disiplin ilmu, tetapi juga dari batas-batas ruang dan waktu (space and time), corak berpikir (worldviews) atau 'urf dalam istilah teknis keilmuan Islam. Yakni, antara corak dan budaya berpikir era classical, medieval, modern dan postmodern. ${ }^{5}$ Pori-pori tersebut ibarat lobang angin pada dinding (ventilasi) yang berfungsi sebagai pengatur sirkulasi keluar-masuknya udara segar dan saling tukar menukar informasi antar berbagai disiplin keilmuan dan menghindari ego keilmuan. Masing-masing disiplin ilmu, berikut worldview, budaya pikir,

3. Holmes Rolston, III, Science and Religion: A Critical Survey (New York: Random House, Inc.,1987), h. 1.

4. M. Amin Abdullah, Islamic Studies di Perguruan Tinggi: Pendekatan Integratif-interkonektif (Yogyakarta: Pustaka Pelajar, 2006), h. 107.

5. Paska terbitnya buku Jasser Auda Maqasid al-Shari'ah as Philosophy of Islamic Law: A Systems Approach, (London: The International Institute of Islamic Thought, 2008), saya terbantu dengan gambar ilustrasinya pada halaman 58, 196 dan 204. Hanya saja istilah dan pemahaman semipermeable kurang mendapat tekanan disitu. 
tradisi atau 'urf yang menyertainya dapat secara bebas saling berkomunikasi, berdialog, menembus-mengirimkan pesan dan masukan temuan-temuan yang fresh di bidangnya ke disiplin ilmu lain di luar bidangnya. Ada pertukaran informasi keilmuan dalam suasana bebas, nyaman dan tanpa tekanan, jaga gengsi dan beban sejarah masa lalu.

Masing-masing disiplin ilmu masih tetap dapat menjaga identitas dan eksistensinya sendiri-sendiri, tetapi selalu terbuka ruang untuk berdialog, berkomunikasi dan berdiskusi dengan disiplin ilmu lain. Tidak hanya dapat berdiskusi antar rumpun disiplin ilmu kealaman secara internal, namun juga mampu dan bersedia untuk berdiskusi dan menerima masukan dari keilmuan external, seperti dengan ilmu-ilmu sosial dan humaniora. Ilmu-ilmu agama atau yang lebih populer disebut dengan 'Ulumu al-din tidak terkecuali disini. Ia juga tidak dapat berdiri sendiri, terpisah, terisolasi dari hubungan dan kontak dengan keilmuan lain di luar dirinya. Ia harus terbuka dan membuka diri serta bersedia berdialog, berkomunikasi, menerima masukan, kritik, berkolaborasi dan bersinergi dengan keilmuan alam, keilmuan sosial dan humaniora.

Tidak ada disiplin ilmu apapun yang dapat menutup diri, tidak ada disiplin ilmu yang tertutup oleh pagar dinding dan batas-batas ketat yang dibuatnya sendiri. Batas masing-masing disiplin ilmu masih tetap ada dan kentara, seperti yang tergambar dalam eksistensi program-program studi di perguruan tinggi, tapi batas-batas itu bukannya kedap sinar dan kedap suara. Tersedia lobanglobang kecil atau pori-pori yang melekat pada dinding pembatas disiplin keilmuan yang dapat dirembesi atau dimasuki oleh masukan disiplin ilmu lain. Gambaran komunitas ilmuan dan komunitas peneliti sekarang memang bukan lagi seperti era dulu lagi yang hanya menghimpun keahlian dalam satu disiplin ilmu, tetapi menghimpun dan siap mendengarkan masukan dari berbagai disiplin ilmu yang berbeda. Di sini, konsep linearitas bidang ilmu - meskipun sah-sah saja jika ditinjau dari administrasi birokrasi keilmuan, tapi menurut pandangan keilmuan generasi ketiga perguruan tinggi, ${ }^{6}$ konsep tersebut dipertanyakan oleh banyak kalangan ilmuan itu sendiri. Berikut kutipan dari pendapat Holmes Rolston, III:

"The religion that is married to science today will be a widow tomorrow. The sciences in their multiple theories and forms come and go. Biology in the year 2050 may be as different from the biology of today as the religion of today is from the religion of 1850 . But the religion that is divorced from science today will leave no offspring tomorrow. From here onward, no religion can reproduce

6 J.G. Wissema, Towards the Third Generation University: Managing the University in Transition,UK, Edwards Elgar, 2009, h. 23. 
itself in succeeding generations unless it has faced the operations of nature and the claims about human nature with which confronts us. The problem is somewhat like the one that confronts a living biological species fitting itself into its niche in the changing environment: There must be a good fit to survival, and yet overspecialization is an almost certain route to extinction. Religion that has too thoroughly accomodated to any science will soon be obsolete. It needs to keep its autonomous integrity and resilience. Yet religion cannot live without fitting into intellectual world that is its environment. Here too the fittest survive."?

Terjemahan bebas, kurang lebih sebagai berikut. "Agama yang kawin dengan ilmu pengetahuan sekarang akan menjadi duda esok hari. Ilmu dengan berbagai teori dan bentuknya akan datang dan pergi. Biologi tahun 2050 akan berbeda dari biologi yang kita tahu sekarang sebagaimana (pemahaman) agama era sekarang juga berbeda dari (pemahaman) agama tahun 1850. Namun, agama yang bercerai dari ilmu pengetahuan tidak akan mampu menurunkan keturunan yang baik di masa yang akan datang. Dari saat sekarang ke depan, tidak ada agama yang mampu memproduksi dirinya pada generasi selanjutnya tanpa tidak berhadapan dengan cara bekerjanya alam semesta dan juga klaimklaim pengetahuan tentang hakikat manusia yang selalu kita jumpai. Persoalan yang dihadapi mirip-mirip seperti yang dihadapi oleh spesies biologis yang hendak menyesuaikan dirinya dalam lingkungan hidup yang berubah. Harus ada kemampuan untuk menyesuaikan diri yang kuat supaya dapat bertahan hidup, meskipun begitu harus segera digarisbawahi bahwa spesialisasi disiplin ilmu pengetahuan yang berlebihan (overspecialization) adalah jalan pasti ke arah kepunahan.

Agama yang secara total terserap ke dalam pangkuan hegemoni ilmu pengetahuan juga akan kadaluwarsa. Karenanya, ia perlu menjaga integritasnya secara otonom dan menjaga daya kebertahanannya. Namun harus segera dicatat juga bahwa agama tidak dapat bertahan hidup tanpa sama sekali menyesuaikan dengan perkembangan dunia intelektual, yakni lingkungan hidup sekitarnya. Di sini juga berlaku lagi kaidah bahwa hanya yang mampu menyesuaikan diri dan beradaptasi dengan baik lah yang akan mampu bertahan hidup.

Dari kutipan dan uraian di atas tampak mengapa masih ada beberapa tokoh elite agama, ustadz, pendakwah, kyai, pastor, pendeta, bhikku, pedanda, bahkan umat beragama secara umum di sebagian masyarakat yang enggan bahkan menolak ajakan dan himbauan pemerintah berdasarkan masukan ilmu pengetahuan kesehatan dan kedokteran lewat PSBB untuk menghindari kerumunan dalam penyelenggaraan ibadah, khususnya di zona merah, karena

7. Holmes Rolston, III, Op. cit. h. vii. Cetak miring dan tebal dari saya. 
mereka belum mampu dan tidak bersedia mendialogkan, mengkompromikan, apalagi mengintegrasikan keyakinan dan keilmuan agama yang mereka miliki dengan perkembangan kemajuan sains melalui penelitian di laboratorium yang berkesinambungan. Keilmuan agama yang dikuasai belum sempat diperbaharui metode, pendekatan dan datanya. Keilmuan agama yang belum tercerahkan. Keilmuan agama yang "arogan”, yang "egois”, karena steril dan menghindari perjumpaan dan perbincangan dengan keilmuan alam, sosial dan humaniora yang menjadi tuntutan lingkungan sosial dan intelektual baru di tengah upaya pemerintah dan masyarakat dunia untuk mencegah penyebaran pandemi Covid-19 yang mematikan. ${ }^{8}$

\section{Keterujian Intersubjektif}

Rambu-rambu kedua yang menandai hubungan antara ilmu dan agama yang bercorak dialogis dan integratif adalah Intersubjective Testability (keterujian intersubjektif). Istilah tersebut datang dari Ian G. Barbour dalam konteks pembahasan tentang cara kerja sains kealaman dan humanities, ${ }^{9}$ namun dalam tulisan ini akan saya kembangkan dengan menggunakan ilustrasi yang diambil dari pendekatan fenomenologi agama. Menurut Barbour baik Objek (objek yang diteliti) maupun Subjek (peneliti; ilmuan) masing-masing berperan besar dalam kegiatan keilmuan. Data tidak dapat dikatakan terlepas sama sekali dari penglihatan pengamat (The data are not "independent of the observer"), karena situasi di lapangan selalu diintervensi oleh ilmuan sebagai experimental agent itu sendiri. Oleh karenanya, concepts bukanlah diberikan begitu saja oleh alam, namun dibangun atau dikonstruk oleh ilmuan itu sendiri sebagai pemikir yang kreatif (creative thinker). Oleh karenanya, pemahaman tentang apa yang disebut objektif harus disempurnakan menjadi intersubjective testability, yakni ketika semua komunitas keilmuan ikut bersama-sama berpartisipasi menguji tingkat kebenaran penafsiran dan pemaknaan data yang diperoleh peneliti dan ilmuan dari lapangan. ${ }^{10}$

Dalam dunia logika ilmu pengetahuan sekarang, khususnya yang terkait dengan bahasan ilmu dan agama, dikenal istilah subjektif, objektif dan berikutnya

8. Holmes Rolston III memberi sifat kepada teori keilmuan apapun yang merasa cukup dengan dirinya sendiri, tidak bersedia menerima masukan dan pengalaman dari teori dan disiplin ilmu lain dengan istilah "blik". Blik adalah teori yang berkembang secara arogan, terlalu keras dan alot untuk dilunakkan oleh pengalaman (A blik is a theory grown arrogant, too hard to be softened by experience), Holmes Rolston, III, Op. cit. h. 11.

9. Ian G. Barbour, Issues in Science and Religion (New York: Harper Torchbooks, 1966), h.182-185. Juga karyanya yang telah diterjemahkan ke dalam bahasa Indonesia, Juru Bicara Tuhan: Antara Sains dan Agama (When science meets religion: Enemies, Strangers or Partners?, 2000), terjemahan E.R. Muhammad (Bandung: Penerbit Mizan, 2002).

10. Ian G. Barbour, Ibid. h. 183 
intersubjektif. ${ }^{11}$ Dalam studi agama, khususnya kajian fenomenologi agama lewat bantuan penelitian antropologi melalui grounded research (etnografi) - para peneliti (observer; researchers) dapat mencatat apa yang ditemui dalam kehidupan sehari-hari di lapangan hal-hal yang dapat dideskripsikan secara objektif. Para peneliti antropologi agama menemukan dan mencatat dengan cermat bahwa apa yang disebut agama atau fenomena agama antara lain meliputi unsur-unsur dasar sebagai berikut : 1) doktrin (believe certain things), 2) ritual (perform certain activities), 3) kepemimpinan (invest authority in certain personalities), 4) nass/ teks kitab suci (hallow certain texts), 5) sejarah (tell various stories), 6) moralitas (legitimate morality) dan bisa ditambah 7) alat-alat (tools). ${ }^{12}$ Ketujuh unsur ini pada umumnya ada secara objektif dalam masyarakat pengikut agama dan kepercayaan di manapun mereka berada. Namun, para pengamat, researchers dan ilmuan (subjek) lah yang mengkonstruk dan mencatat adanya unsur-unsur dasar (fundamental structure) dalam kehidupan beragama tersebut.

Ketika ketujuh unsur dasar dalam agama, yang menurut penglihatan para pengamat (researchers; religious scholars) bersifat objektif universal -karena dapat ditemui dimana-mana- tersebut telah dimiliki, diinterpretasikan, dipahami, dipraktikkan dan dijalankan oleh orang per orang, kelompok per kelompok dalam konteks budaya dan bahasa tertentu (community of believers), maka secara pelan tapi pasti, apa yang dianggap objektif oleh para pengamat tadi akan berubah menjadi subjektif menurut tafsiran, pemahaman dan pengalaman para pengikut ajaran agama atau kepercayaan masing-masing. Community of believers ini seringkali sulit sekali memahami sisi objektivitas dari keberagamaan manusia, karena kepentingan-kepentingan memang selalu melekat dalam dunia subjek dan para pelaku di lapangan.

Pergeseran dari objektivitas-peneliti ke subjektifitas-pelaku, setidaknya, dapat ditandai ketika apa yang diyakini, dipahami, ditafsirkan dan dijalani oleh orang per orang, kelompok per kelompok dan golongan per golongan atau masyarakat tertentu dianggap dan dipercayai sebagai sesuatu yang tidak dapat dipersalahkan, tidak dapat diganggu-gugat, absolut, tidak dapat diperdebatkan sama sekali (non-falsifiable) dan tidak dapat diperbandingkan dengan yang lain (incommensurable). Ketika terjadi proses sosiologis dan psikologis seperti itu, maka apa yang dulunya tampak objektif oleh para pengamat, researchers, scholars

11. Joseph A. Bracken, Subjectivity, Objectivity \& Intersubjectivity: A New Paradigm for Religion and Science (Pennsylvania: Templeton Foundation Press, 2009).

12. James L. Cox, A Guide to the Phenomenology of Religion: Key Figures, Formative Influences and Subsequent Debates (London: The Continuum International Publishing Group, 2006), h. 236. Bandingkan dengan Ninian Smart, Dimensions of the Sacred: An Anatomy of the World's Beliefs (London: Fontana Press, 1977). 
telah bergeser ke wilayah subjektif oleh para pelaku dan penganut agama-agama dan kepercayaan yang ada di lapangan. Klaim bahwa virus Korona adalah tentara Tuhan untuk menghancurkan dan membinasakan manusia yang tidak mengenal Tuhan, manusia yang hidup berlumuran dosa, misalnya adalah contoh dari klaim subjektif. Klaim ini menepikan realitas adanya makhluk virus yang secara objektif memang menyebar dan membunuh pasien yang terjangkit, virus yang dapat dilihat dan ditemukan oleh para peneliti bidang kedokteran di ruang laboratorium.

Di sini letaknya tikungan tajam, di mana orang apalagi kelompok seringkali kehilangan kompas dan petunjuk arah perjalanan ke depan. Jika para pengamat, peneliti, ilmuwan dan sarjana agama (religious scholars) melihat kepelbagaian dan kemajemukan interpretasi dalam agama-agama (baik secara eksternal antar pengikut agama-agama maupun secara internal, dalam lingkungan dalam agama itu sendiri) sebagai suatu hal yang secara sosiologis wajar belaka dan kemudian para pengamat dan ilmuwan berusaha mencari "esensi" dari kepelbagaian dalam keberagaman (essences and manifestations), maka sebaliknya bagi para pelaku dan aktor agama dan kepercayaan di lapangan (believers dan confessionalist). Bagi para believers, apa yang dipercayai dan diyakininya adalah yang paling benar, absolut, dan tidak dapat dan tidak boleh dipertanyakan oleh siapapun, apalagi dipersalahkan oleh kelompok lain yang berbeda (Nonfalsifiable).

Letak tikungan tajam dan krusialnya ada di sini. Menurut pandangan objektifkeilmuan (scholarly perspective), di tengah kepelbagaian dan kebinnekaan agama secara sosiologis (manifestations), maka yang perlu dicari adalah "essences" (hakikat dan ma'rifat dalam bahasa tasawwuf/sufism nya) dari berbagai agama yang berbeda tersebut, sedang menurut pola pikir agama yang bercorak subjektifis-fiqhiyyah (Islamic/Christian/Buddhist/Hindu/Confusionist perspective, atau agama dan kepercayaan yang lain), maka hanya agama dan kepercayaannya yang dimiliki oleh diri dan kelompoknya (manifestations; Syari'ah) sajalah yang paling benar (nonfalsifiable). Implikasi dan konsekwensi dari dua model berpikir ini sudah dapat diperkirakan. Indonesia dan dunia agama-agama di manapun berada menghadapi persoalan dan permasalahan pelik yang sama seperti itu karena tidak mungkin akan muncul titik temu dan common plaform untuk bertidak secara bersama-sama.

Ketegangan (tension) selalu ada antar kedua corak berpikir tersebut. Para religious leaders dan community leaders perlu memperoleh bekal yang lebih dari cukup untuk dapat mengelola dan menjembatani perbedaan penafsiran dan tension tersebut. 
Dengan begitu, apakah agama dan kehidupan beragama bersifat objektif atau subjektif? Jawaban atas pertanyaan ini sangat menentukan bagaimana corak kehidupan beragama dalam masyarakat multietnis, multibahasa, multireliji, multiras dan multikultural seperti di tanah air. Termasuk bagaimana umat beragama menghadapi pendemi Covid-19 yang sepenuhnya adalah wilayah sains. Harus jujur dikatakan dan diakui bahwa bidang ilmu dan penelitian kealaman yang memerlukan riset di ruang laboratorium dengan tekun, berkesinambungan dan dana yang tidak murah adalah yang sama sekali bukan bidang keahlian para ahli agama tradisional. ${ }^{13}$

Penelitian agama dan pemahaman agama memang unik, sui generis. Tidak dapat disamakan begitu saja dengan penelitian di bidang sains kealaman dan juga sains sosial. Karena dalam agama ada unsur yang hampir sama sekali tidak dapat ditinggalkan, yaitu "involvement" (keterlibatan penuh) dan "unreserved commitment" (komitmen yang tidak bisa ditawar-tawar). ${ }^{14}$ Oleh karenanya, penelitian dan pemahaman agama selalu bercorak objective-cum-subjective dan atau objective-cum-subjective. Dalam agama ada unsur objektifitas, namun dalam waktu yang bersamaan, pemahaman dan penafsiran agama selalu lekat di dalamnya unsur subjektifitas. Begitupun sebaliknya, agama pada hakikatnya adalah bercorak subjektif (fideistic subjectivism), ${ }^{15}$ namun akan segera menjadi absurd, dan mungkin akan menjadi anarkis jika seseorang dan lebih-lebih jika sekelompok orang agamawan yang terhimpun dalam mazhab, sekte, denominasi dan organisasi, jatuh pada fanatisme buta dan menolak koleganya yang lain yang menafsirkan, menganut dan mempercayai kepercayaan dan agama yang berbeda. Untuk menghindari keterjebakan subjektifitas yang akut, maka para agamawan perlu mengenal adanya unsur-unsur objektif (scientific objectivism) yang ada dalam agama-agama, apalagi dalam wilayah ilmu pengetahuan yang objektif (hard sciences) seperti kesehatan, farmasi dan kedokteran. Dengan begitu, ketegangan yang ada dalam wilayah a dire subjectivism yang biasa diwakili oleh pemahaman keagamaan yang bercorak literalis-skripturalis dan absolutis dapat diredakan melalui pencerahan wawasan keilmuan (einlightenment) lewat pengenalan wilayah objektif dalam pemahaman agama-agama dan wilayah ilmu-

13. Dalam ungkapan bahasa yang agak keras-sarkastik, Harari mendeskripsikan sebagai berikut: “... Now ask yourself: what the most influential discovery, invention or creation of traditional religions such as Islam and Christianity in the twentieth century? This too is a very difficult question, because there is so little to choose from. What did priests, rabbis and muftis discover in the twentieth century that can be mentioned in the same breath as antibiotics, computers or feminism?...". Lebih lanjut Yuval Noah Harari, Homo Deus: A Brief History of Tomorrow (New York: Harper. Perennial, 2017), h. 277.

14. Ian G. Barbour, Op. cit., h. 218-9.

15. Richard C. Martin (Ed.), Approaches to Islam in Religious Studies, (Tucson: The University of Arizona Press, 1985), h. 2 
ilmu kealaman lewat penelitian empiris (al-muqarabah al-maidaniyyah). Wilayah objektif dan subjektif dalam studi agama, begitu juga dalam wilayah disiplin ilmu yang lain tidak dapat dipisahkan.

Setelah mengenal pergumulan antara dunia objektif dan dunia subjektif dalam studi agama, yang dapat diformulasikan menjadi objective-cum-subjective dan atau subjective-cum-objective, maka kluster berpikir berikutnya, yaitu "intersubjektif" akan lebih mudah dipahami. Intersubjektif adalah posisi mental keilmuan (scientific mentality) yang dapat mendialogkan dengan sigap dan cerdas antara dunia objektif dan subjektif dalam diri seorang ilmuwan atau agamawan dalam menghadapi kompleksitas kehidupan, baik dalam dunia agama, sains, maupun budaya. Intersubjektif tidak hanya dalam wilayah agama, tetapi juga pada dunia keilmuan pada umumnya. Communtiy of researchers selalu bekerja dalam bingkai intersubjective testability. Kehidupan yang begitu kompleks, tidak dapat diselesaikan dan dipecahkan hanya dengan satu bidang disiplin ilmu. Overspecialization dan linearitas bidang ilmu menjadi bahan perbincangan dan perdebatan sekarang. Wabah virus korona tidak dapat diselesaikan oleh sains sendiri, terlepas dari bantuan keilmuan lain karena dalam praktik di lapangan diperlukan keilmuan sosial dan humaniora ketika hendak menegakkan aturan social dan physical distancing.

Begitu pula ilmu-ilmu agama. Penganut agama yang terkena wabah virus korona, selain berdoa dan didoakan oleh yang lain, juga perlu melangkah kaki untuk berobat ke rumah sakit untuk diterapi secara medis, yang sepenuhnya menggunakan metode ilmu pengetahuan objektif melalui pemeriksaan laboratorium yang ketat $^{16}$ Semua memerlukan kerendahan hati dan kerjasama, bukan egoisme dan arogansi keilmuan. Kolaborasi dan integrasi antara berbagai disiplin ilmu sangat diperlukan untuk memecah kebekuan pandangan keilmuan yang terisolasi dan memecahkan berbagai macam kompleksitas kehidupan di era post-modernitas. Masukan dan kritik dari berbagai disiplin (multidicipline) dan lintas disiplin ilmu (transdicipline) menjadi sangat dinantikan untuk dapat memahami kompleksitas kehidupan dengan lebih baik. Linearitas bidang ilmu yang dipahami secara ad hoc akan mempersempit wawasan seseorang, jika berhadapan dengan isi-isu keilmuan yang berada di luar jangkauan bidang keilmuannya.

16. Untuk melihat secara sekilas bagaimana ilmu kedokteran dan kesehatan bekerja keras untuk menanggulangi wabah virus korona, lebih lanjut Sutaryo dkk, Buku Praktis Penyakit VIRUS CORONA 19 (COVID-19), (Yogyakarta: Gadjah Mada University Press, 2020). 


\section{Imajinasi Kreatif}

Meskipun logika berpikir induktif dan deduktif telah dapat menggambarkan secara tepat bagian tertentu dari cara kerja ilmu pengetahuan, namun sayang dalam uraian tersebut umumnya meninggalkan peran Creative Imagination (imajinasi kreatif) dari ilmwuan itu sendiri dalam kerja ilmu pengetahuan. Memang ada logika untuk menguji teori tetapi tidak ada logika untuk menciptakan teori. Tidak ada resep yang jitu untuk membuat temuan-temuan yang orisinal. Diperlukan semacam ilham, intuisi, feeling, rasa, inspirasi, pengalaman dan sensitivitas tingkat tinggi.

Umumnya para ilmuwan bercita-cita dalam karir akademisnya untuk dapat menemukan teori baru. Mahasiswa program doktor pun selalu dihimbau oleh promotornya untuk menyuguhkan temuan baru sebagai sumbangsih pengembangan ilmu pengetahuan (contribution to knowledge). Bagaimana teori baru itu muncul? Teori baru seringkali muncul dari keberanian seorang ilmuwan dan peneliti untuk mengkombinasikan berbagai ide-ide yang telah ada sebelumnya, namun ide-ide tersebut terisolasi dari yang satu dan lainnya. Menurut Koesler dan Ghiselin, ${ }^{17}$ bahwa imajinasi kreatif baik dalam dunia ilmu pengetahuan maupun dalam dunia sastra seringkali dikaitkan dengan upaya untuk memperjumpakan dua konsep framework yang berbeda. Ia mensintesakan dua hal yang berbeda dan kemudian membentuk keutuhan baru, menyusun kembali unsur-unsur yang lama ke dalam adonan konfigurasi yang fresh, yang baru. Bahkan seringkali teori baru muncul dari upaya yang sungguh-sungguh untuk menghubungkan dua hal yang sebenarnya tidak berhubungan sama sekali. Newton menghubungkan dua fakta yang sama-sama dikenal secara luas, yaitu jatuhnya buah apel dan gerak edar atau rotasi bulan. Sedang Darwin melihat adanya analogi antara tekanan pertumbuhan penduduk dan daya tahan hidup species binatang. Ada pararelitas antara kreativitas dalam bidang ilmu pengetahuan (scientist) dan seni (artist). Campbell, sebagaimana dikutip Ian G. Barbour, menulis sebagai berikut:

"For it has been admitted that though discovery of laws depends ultimately not on the fixed rules but on the imagination of highly gifted individuals, this imaginative and personal element is much more prominent in the development of theories; the neglect of theories leads directly to the neglect of the imaginative and personal element in science. It leads to an utterly false contrast between "materialistic" science and the "humanistic" studies of literature, history and art. ... What I want to impress on the reader is how purely personal was Newton's idea. His theory of universal gravitation, suggested to him by the trivial fall of an

17. Ian G. Barbour, Op. cit., h. 143. 
apple, was a product of his individual mind, just as much as the Fifth Symphony (said to have been suggested by another trivial incident, the knocking at a door) was a product of Beethoven's." 18

Bagaimana jika uraian tersebut dihubungkan dengan kondisi pemikiran, hukum, pendidikan dalam budaya masyarakat Muslim kontemporer? Adalah waktunya sekarang untuk mulai berani berpikir ulang tentang pemikiran dan praktik kependidikan keagamaan dan keislaman dengan memandang perlunya menggunakan imajinasi kreatif dalam proses pembelajaran dan perkuliahan. Ilmu-ilmu keagamaan Islam era sekarang, sebutlah sebagai contoh seperti fikih, ibadah, kalam/aqidah/tauhid, tafsir, hadis, tarikh, akhlak, tidak boleh lagi steril dari perjumpaan, persinggungan dan pergumulannya dengan disiplin keilmuan lain di luar dirinya. Pendidikan keagamaan secara umum dan keislaman secara khusus tidak dapat lagi disampaikan kepada peserta didik dalam keterisolasiannya dan ketertutupannya dari dialog, interaksi dan masukan dari disiplin ilmu-ilmu lain dan begitu juga sebaliknya. Guru dan dosen perlu berpikir kreatif dan memiliki imajinasi kreatif, berani mengkaitkan, mendialogkan uraian dalam satu bidang ilmu agama dalam kaitan, diskusi dan perjumpaannya dengan disiplin keilmuan lain. Apabila langkah ini tidak dilakukan, maka pelajaran agama di sekolah, juga ceramah-ceramah keagamaan lewat media sosial, apalagi perkuliahan agama di perguruan tinggi, lambat laun akan terancam kehilangan relevansi dengan permasalahan kehidupan sekitar yang sudah barang tentu semakin hari semakin kompleks.

Kasus-kasus yang disebut dalam pengantar tulisan ini mencerminkan tiadanya creative imagination yang mampu menghubungkan dan mendialogkan dalam diri seseorang, apalagi kelompok, antara keilmuan fikih dan aqidah, keimanan, doktrin keagamaan di satu sisi dan sains kontemporer di sisi lain. Tidak dapat berdialog dan terintegrasikannya keilmuan Kalam/Aqidah/Tauhid dan Fikih ('Ulumu al-din) dengan pengalaman, keahlian dan praktik sains kesehatan, kedokteran dan farmasi serta sosial humanitas kegotongroyongan sosial untuk bersama-sama mencegah tersebarnya virus korona yang menjadi pandemi dunia sekarang ini adalah bentuk konkret dari corak hubungan antara agama dan ilmu yang bersifat Konflik dan/atau Independen.

Tidak adanya proses intersubjective testability antara dua bidang ilmu atau lebih (multidiciplinary approach) menjadikan pemahaman dan penafsiran agama - yang umumnya hanya mendasarkan dan mengikuti nass-nass atau teks-teks keagamaan yang telah tersedia - menjadi terisolasi dari kehidupan sekitar - baik

18. Ian G. Barbour, Op. cit. h. 144. Cetak miring dan hitam tambahan dari saya. 
dalam arti lokal, regional, nasional maupun global - sehingga mudah terasa obsolete atau outdated (tidak relevan; krisis relevansi; kadaluwarsa) dan bahkan dapat menimbulkan korban sosial yang sesungguhnya tidak perlu. Kehidupan dan keilmuan agama terjebak dalam mindset lama yang tertutup, rigid, kaku dan tidak mampu berdialog secara jujur dan terbuka dengan disiplin dan pengalaman keilmuan lain. ${ }^{19}$ Kriteria semipermeable ${ }^{20}$ dalam format integrasi-interkoneksi keilmuan tidak jalan sama sekali sehingga ketika manusia beragama dihadapkan pandemi virus korona diikuti dengan kebijakan karantina kesehatan dan PSBB, lebih banyak menimbulkan keraguan, ketegangan, kewaswasan, keluh kesah, kegalauan dan kepanikan.

\section{Agama, Ilmu dan Budaya}

Bagian terakhir dari tulisan ini menjelaskan bagaimana para pemikir Muslim kontemporer berpikir keras menghadapi situasi dan sejarah yang telah berubah, tanpa kehilangan fondasi, semangat dan spiirit religious-culturalnya. Bagaimana mereka menggunakan kriteria semipermeable, intersubjective testability dan creative imagination dalam bangunan konsep keilmuannya, dalam upaya mengembangkan disiplin ilmu keagamaan Islam dalam hubungan dan dialognya dengan disiplin ilmu-ilmu alam, sosial dan humaniora di era kontemporer. Bagaimana upaya mereka menjembatani ketegangan yang selalu ada antara "objektifitas" dan "subjektifitas", antara wilayah "sains" dan "agama"? Mungkinkah kriteria objective-cum-subjective dan atau subjective-cum-objective diaplikasikan dalam keilmuan agama (Islam) yang disempurnakan?

Tidak ada yang dapat menyangkal jika dikatakan bahwa dalam 100 sampai 150 tahun terakhir, sejarah umat manusia mengalami perubahan yang luar biasa. Terjadi perubahan yang luar biasa dalam sejarah manusia dalam mengatur dan memperbaiki kualitas kehidupan dalam berhubungan dengan alam, manusia dan Tuhannya. Perubahan yang dahsyat dalam perkembangan ilmu pengetahuan, tatanan sosial-politik dan sosial-ekonomi, energi, hukum, tata kota, lingkungan hidup dan begitu seterusnya. Perubahan dahsyat tersebut, menurut Abdullah Saeed, antara lain terkait dengan globalisasi, migrasi penduduk, kemajuan sains

19. Bandingkan dengan pernyataan Jasser Auda sebagai berikut: "Without incorporating relevant ideas from other diciplines, research in the fundamental theory of Islamic law will remain within the limits of traditional literature and its manuscripts, and Islamic law will continue to be largely 'outdated' in its theoretical basis and practical outcomes. The relevance and need for a multidisciplinary approach to the fundamentals of Islamic law is one of the argument of this book." Op. cit., h. xxvi.

20. Abdol Karim Soroush menggunakan istilah "interpenetration" dalam teori al-Qabt wa al-Bast (Penyempitan dan Perluasan) fi al-Syari'ah. Lebih lanjut Mahmoud Sadri Ahmad Sadri (ed.), Reason, Freedom, and Democracy in Islam: Essential Writings of Abdolkarim Soroush, (Oxford: Oxford University Press, 2000), h.26-38. 
dan teknologi, eksplorasi ruang angkasa, penemuan-penemuan arkeologis, evolusi dan genetika, pendidikan umum dan kemajuan tingkat literasi umat manusia. Diatas itu semua adalah bertambahnya pemahaman dan kesadaran tentang pentingnya menghormati dan menjunjung tinggi harkat dan martabat manusia (human dignity), perjumpaan yang lebih dekat antar umat beragama (greater inter-faith interaction), munculnya konsep negara-bangsa yang berdampak pada kesetaraan dan perlakuan yang sama kepada semua warga negara (equal citizenship), belum lagi kesetaraan gender dan begitu seterusnya. Perubahan sosial yang dahsyat tersebut berdampak luar biasa dan mengubah pola berpikir dan pandangan keagamaan (religious world view) baik di lingkungan umat Islam maupun umat beragama yang lain. ${ }^{21}$

Meskipun perubahan ada dimana-mana, termasuk pengetahuan manusia juga bergerak, tumbuh dan berkembang, namun tetap saja ada masalah di bidang keilmuan agama. Ketika pemerintah menghimbau agar dilakukan social dan physical distancing untuk menghindari penyebaran virus korona secara masif, dikenal dengan sebutan Pembatasan Sosial Berskala Besar (PSBB), masih banyak warga negara dan umat beragama - agama apapun yang dianutnya tidak atau kurang mematuhinya dengan alasan teologis. Masih seringkali dijumpai pemahaman dan keyakinan bahwa (pengetahuan) agama Islam diyakini dan dianggap sebagai absolut (absolute), tidak dapat diubah (immutable) dan transcendental (selalu terkait dengan zat yang berada diatas/suci/agung). Pemahaman, penafsiran dan pengetahuan agama (Islam) yang dianggap dan dipercayai tidak dapat berubah, absolut, rigid, kaku, tidak bisa dikompromikan dengan konteks dan situasi pencegahan menyebarnya wabah korona seperti itulah yang kini sedang dikritisi oleh para ilmuwan dan cerdik pandai era sekarang, sebagaimana yang dinyatakan oleh Nidhal Guessoum, ilmuan Muslim berkebangsaan Aljazair, sebagai berikut:

"... The next important issue is the need to engage the Islamic scholars in a serious dialogue and convince them that scientists have much to say on topics that have for too long remained the monopoly of the religious scholars and their discourse. While there is no doubt in people's minds that human knowledge evolves and grows, it is often understood that religions, especially Islam, are (is) absolute, immutable and transcendent principles, which are set in rigid frames of reference. But we know today that religions - and Islam is no exception cannot afford to adopt a stationary attitude, lest they find themselves clashing

21. Abdullah Saeed, Interpreting the Qur'an: Towards a Contemporary Approach (New York NY: Routledge, 2006), h. 2. 
with and overrun by modern knowledge, and religious principles appear more quaint and obsolete."22

Terjemahan bebasnya sebagai berikut. "Permasalahan berikutnya yang sangat mendesak adalah bagaimana mengupayakan agar para ulama, mufti, ustadz, kyai, guru, dosen agama Islam mau bersedia untuk berdialog dan berunding dengan para saintis-ilmuan dan meyakinkan mereka bahwa banyak hal dan masalah yang telah sekian lama hanya dimonopoli atau dihegemoni oleh otoritas ulama dan dalam genggaman perbincangan internal mereka. Padahal banyak orang tahu bahwa ilmu pengetahuan terus berubah dan berkembang, namun seringkali dipahami bahwa agama-agama, khususnya Islam adalah absolut/mutlak, tidak berubah dan dibalut dalam prinsip-prinsip transendental dalam wujud pagar rujukan (kelimuan aqidah dan fikih). Namun kita sekarang tahu bahwa agama-agama - dan agama Islam tidak terkecuali - tidak mungkin dapat bertahan mempertahankan sikap jalan di tempat, kaku dan bekunya, jika mereka tidak ingin berbenturan atau digilas oleh ilmu pengetahuan modern, dan prinsip-prinsip dasar agama semakin hari semakin tampak aneh, tertinggal dan kadaluwarsa”.

Dalam khazanah pemikiran keagamaan Islam, khususnya dalam pendekatan Usul al-Fiqh (Kaidah dasar ilmu fikih), dikenal istilah al-Tsawabit (hal-hal yang diyakini "tetap", tidak berubah) wa al-Mutaghayyirat (hal-hal yang diyakini "berubah-ubah", tidak tetap). Ada juga yang menyebutnya sebagai "al-Tsabit" wa "al-Mutahawwil". ${ }^{23}$ Keduanya kemudian lebih popular dengan sebutan Qath'iy (pasti) dan Dzanniy (tidak pasti). Sedang dalam pendekatan Falsafah (philosophy), sejak Aristoteles hingga sekarang, dikenal apa yang disebut "Form" and "Matter",

22. Nidhal Guessoum, Islam's Quantum Question: Reconciling Muslim Tradition and Modern Science (London dan New York: I.B. Tauris and Co Ltd., 2011), h. 343-4. Cetak miring dan hitam dari saya. Bandingkan dengan pendapat Abdolkarim Soroush yang menegaskan bahwa untuk memecah kebekuan berpikir sebagian para agamawan diperlukan secara jelas dan tegas pembedaan secara konseptual antara "agama" dan "pemikiran atau penafsiran tentang agama". Yang pertama memang tidak bisa diubah-ubah, namun pemikiran dan penafsiran agama pasti dan harus bisa diubah dan berubah untuk perbaikan dan penyempurnaan karena perkembangan peradaban dan ilmu pengetahuan. Lebih lanjut Abdul-Karim Soroush "The Evolution and Devolution of Religious Knowledge" dalam Kurzman, Charles Kurzman, (Ed.), Liberal Islam: A Sourcebook (Oxford: Oxford University Press, 1998), h.245-6.

23. Adonis, al-Tsabit wa al-Mutahawwil: Bahts fi al-ibda' wa al-itba' 'inda al-arab (London: Dar alsaqi,2002). 
One-Many, Universal-Particular, Objectif-Subjectif. ${ }^{24}$ Belakangan di lingkungan khazanah keilmuan antropologi (agama), khususnya dalam lingkup pendekatan fenomenologi agama, dikembangkan analisis pola pikir yang disebut General Pattern dan Particular Pattern. ${ }^{25}$

Logika berpikir fiqhiyyah-agama (subjektif) maupun falsafiyyah scientifik (objektif) yang bercorak biner ini, jika dipetakan secara lebih historis antropologis, sebenarnya mencakup dan menggabungkan tiga lapis entitas, yaitu (1) Mentifact, yang mencakup value, tata nilai, kepercayaan (belief), pemikiran (thought), ide dan world view secara lebih umum; (2) Socifact, yaitu ketika ide, nilai dan pemikiran tersebut masuk ke dalam dunia sosial, maka ia membentuk kelompok-kelompok, organisasi-organisasi, mazhab-mazhab, denominasi, sekte, paguyuban, komunitas, organisasi berikut pranata sosial yang menyertainya serta behavior (perilaku), attitude (sikap) dan pola-pola hubungan dan interaksi sosial yang kompleks; (3) Artifact. Hubungan antara keduanya diwujudkan dan disimbolkan dalam dunia fisik seperti bangunan tempat beribadah (masjid, gereja, sinagog, vihara, pura, klenteng), lembaga-lembaga (sosial-keagamaan, pendidikan, ekonomi, budaya), manuskrip, naskah-nakah, buku, prasasti, benda-benda seni, alat-alat peribadatan, musik, lukisan, laboratorium, alat-alat transportasi, objek-objek ritual, makam dan begitu seterusnya adalah hal-hal yang tidak terpisahkan dari keterjalinan antara Mentifact dan Sociofact. ${ }^{26}$

Adalah merupakan pertanyaan yang sulit dijawab - namun bukannya tidak dapat diupayakan - bagaimana 'logika berpikir' yang bercorak triadic yang melibatkan tiga komponen berpikir sekaligus tersebut dapat dioperasionalisasikan di lapangan pemikiran dan pendidikan agama, ketika umat beragama pada umumnya dan umat Islam pada khususnya tengah menghadapi perubahan sosial yang begitu dahsyat? Bahkan nilai-nilai dalam wilayah mentifact pun bergerakberubah terus-menerus secara dinamis sesuai dengan dinamika perkembangan

24. Menurut penelitian Josep van Ess, disini lah letak perbedaan yang mencolok antara logika dan cara berpikir Mutakallimun (para ahli teologi Islam) dan Fuqaha (para ahli fikih) di satu sisi dan Falasifah (para ahli filsafat) di sisi lain. "Aristotelian definition, however, presupposes an ontology of matter and form. Definition as used by the mutakallimun usually does not intend to lift individual phenomena to a higher, generic category; it simply distinguishes them from other things (tamyiz). One was not primarily concerned with the problem how to find out the essence of a thing, but rather how to circumscribe it in the shortest way so that everybody could easily grasp what was mean". Lebih lanjut Josep van Ess, "The Logical Structure of Islamic Theology", dalam Issa J. Boullata (Ed.), An Anthology of Islamic Studies (Canada: McGill Indonesia IAIN Development Project, 1992) tanpa halaman. Jasser Auda menambahkan bahwa " ... the jurists' method of tamyiz between concepts, whether essence-or description-based always resulted in defining every concept in relation to a 'binary opposite.' The popular Arabic saying goes...

"Things are distinguished based on their opposites' (bizdiddiha tatamayyaz al-ashya')". Lihat Jasser Auda, Op. cit. h. 212.

25. Richard C. Martin menyebut 'general pattern' sebagai 'common pattern' atau the universals of human religiousness. Op. cit. h. 8.

26. Sartono Kartodidjo, Pendekatan Ilmu Sosial dalam Metodologi Sejarah (Jakarta: Gramedia, 1992), h. 2. 
ilmu pengetahuan, sosial dan kultural vis a vis dengan keyakinan (system of belief) yang juga masih dalam wilayah mentifact bersikukuh bahwa aqidah atau world view keagamaan tidaklah dapat berubah kapanpun dan dimanapun. Dalam praktiknya, tidak mudah mengoperasionalisasikan, mengkaitkan dan mempertimbangkan jalinan hubungan antar ketiganya dalam satu kesatuan yang utuh, tidak terpisah-pisah, di lapangan pemikiran, pendidikan, dakwah, hukum, birokrasi dan begitu seterusnya.

Kesulitan itu antara lain disebabkan karena masing-masing orang dan kelompok (Socifact) seringkali telah terkurung dan terjebak dalam jaringan preunderstanding, taqalid-taqalid, habits of mind, adat kebiasaan (Mentifact) yang telah dimiliki, membudaya dan dalam batas-batas tertentu bahkan membelenggu. Oleh karenanya, banyak keraguan untuk memasuki pembaharuan dan penyempurnaan konsep pemahaman keagamaan serta terjadi benturan di sana-sini, baik pada tingkat person-person atau individu-individu, lebih-lebih pada tingkat sosial dan kelompok-kelompok pengikut mazhab, sekte, denominasi, organisasi sosialkeagamaan di lingkungan internal maupun external umat beragama. ${ }^{27}$

Seperti telah disinggung diatas, seringkali alat analisis entitas berpikir dalam dua tradisi khazanah keilmuan yang berbeda ini, yakni Usul al-Figh (agama) yang bersumber dari teks, nass-nass kitab suci al-Qur'an dan al-hadis yang dipahami secara literal-harfiyah dan Falsafah (filsafat dan sains) yang berdasar pada prinsip logika berpikir dan metode peneltian eksperimental sains seringkali bertentangan, berbenturan dan berseberangan, untuk tidak menyebutnya konflik. Akibatnya sulit sekali dilerai perebutan otoritas wilayah 'territorial' Ushul al-din (struktur fundamental nilai-nilai keberagamaan manusia pada umumnya, yang berlaku secara universal) di satu sisi dan Ushul al-madzhab (dasardasar pemikiran dan pembentukan atau pendirian sekte, mazhab, kelompok, organisasi keagamaan dalam masyarakat) di lain pihak. Semestinya keduanya berjumpa, berdialektika dan bermusyawarah wajar dan damai dalam dunia pikiran dan batin manusia yang paling dalam, tanpa campur tangan eksternalpolitik yang menimbulkan pertikaian dan konflik sosial.

Umat beragama pada umumnya, lebih suka memilih pilihan either or, memilih salah satu dari dua jenis pilihan yang tersedia (fiqhiyyah atau falsafiyyah-ilmiyyah).

27. Dalam kasus tindak kekerasan yang mengatasnamakan agama selalu saja melibatkan jaringan antara mentifact, socifact dan artifact. Pelarangan pembangunan tempat ibadah dan apalagi pengrusakannya (artifact) tidak dapat dilakukan terpisah dan selalu digerakkan oleh corak pemahaman dan berpikir keagamaan yang rigid-kaku-tertutup (mentifact), dan pola hubungan sosial yang tidak harmonis (socifact). Data yang lebih lengkap tentang kompleksitas hubungan antar agama di tanah air dapat diperiksa dalam Laporan Tahunan Kehidupan Beragama di Indonesia tahun 2009 dan 2011 (Center for Religious \& Crosscultural Studies (CRCS), Sekolah Pascasarjana, Universitas Gadjah Mada, Yogyakarta), 2009 dan 2011. 
Corak berpikir binary (memilih antara dua pilihan yang tersedia) inilah yang sekarang dikritisi oleh para ilmuwan Muslim kontemporer, karena corak pilihan ini lebih mengantarkan kepada corak berpikir yang tertutup dan antagonistik, dan kurang kondusif untuk mengantarkan kepada tatanan pola pikir masyarakat yang terbuka dan banyak pilihan. ${ }^{28}$

Jarang umat beragama dapat memilih both (kedua-duanya penting untuk didialogkan). Metode berpikir ad hoc keagamaan sangat sulit menerima corak berpikir filosofis-saintifik (falsafiyyah-ilmiyyah) dan tidak mampu mendialogkan antara keduanya, antara corak berpikir fiqhiyyah-ubudiyyah dan falsafiyyah'ilmiyyah. Dengan demikian, masih jauh dari upaya untuk mendialogkan, apalagi mengintegrasikan antara keduanya. ${ }^{29}$

Perbedaan yang tajam antara kedua tradisi keilmuan dan corak berpikir dalam menganalisis dan memetakan persoalan sosial-keagamaan yang dihadapi dan jalan keluar yang hendak diambil inilah yang menjadi tema sentral dalam upaya merekonstruksi dan membangun paradigma epistemologi keilmuan Islam kontemporer, termasuk di dalamnya trilogi keilmuan pendidikan Islam di sekolah (Aqidah, Ibadah dan Akhlak) yang sedang dicoba dirumuskan ulang secara serius oleh para pembaharu pemikiran Islam antara lain seperti Muhammad Abduh, Fazlur Rahman, Mohammad Iqbal, dan terlebih lagi oleh para teolog dan pemikir Muslim kontemporer seperti yang sebahagian pemikirannya akan saya singgung disini, yaitu Abdullah Saeed (Maldev dan Australia) dan Jasser Auda (Qatr dan Dublin). Pemikir muslim kontemporer yang lain masih banyak. Kedua pemikir Muslim kontemporer tersebut hanya sebagai contoh bagaimana mereka merespons perkembangan zaman dan perubahan sosial yang berlangsung di era sekarang dan implikasinya dalam rancang bangun metode pendidikan dan dakwah Islam yang terbaharui.

Memasuki wilayah hubungan baru antara agama, ilmu dan budaya, perlu disentuh bagaimana struktur dasar bangunan yang melandasi cara berpikir umat

28. Jasser Auda, Op. cit. h.50, 212, 214; 216; 218; 226-7.

29. Diskusi dan pembahasan serius tentang hubungan antara agama dan ilmu (Religion and Science) di tanah air, kalau saya tidak salah mengamati, sangat jarang dilakukan. Kalaupun dilakukan masih dilakukan secara sporadis, tidak terprogram dan terencana, bahkan di lingkungan perguruan tinggi sekalipun. Pemikiran Islam pada umumnya belum atau jarang mendiskusikannya secara serius. Diskusi pada umumnya hanya terbatas pada wilayah akal dan wahyu, yang lagi-lagi kembali ke diskusi antara teologi Mu'tazilah dan Asy'ariyah. Upaya-upaya rintisan awal seperti yang dilakukan oleh Mohammad Abid al-Jabiry, Bunyah al-Aql al-Araby: Dirasah tahliliyyah naqdiyyah li nudzumi al-ma'rifah fi al-tsaqafah al-arabiyyah (Beirut: al-Markaz al-tsaqafy al-araby, 1993), juga Mohammad Shahrur, Nahw Usul al-Jadidah li al-Figh al-Islamy: Figh al-Mar'ah (Damaskus, 2000) dan Nasr Hamid Abu Zaid, Naqd al-Khitab al-Diniy (Qahira: Sina li al-nasyr, 1994) masih sedikit sekali dapat diakses - untuk tidak menyebutnya masih banyak ditolak kehadirannya di berbagai kalangan ilmuwan agama di perguruan tinggi agama, apalagi di lingkungan masyarakat non-perguruan tinggi. 
manusia (humanities) secara umum dan sekaligus juga harus disentuh bagaimana struktur dasar bangunan cara berpikir keagamaan Islam secara khusus ('Ulum al-din). Menyebut epistemologi keilmuan agama atau 'Ulum al-din, mau tidak mau, para ahli, peneliti dan para pengguna jasa keilmuan agama harus bersedia untuk bersentuhan dengan bangunan keilmuan atau pendekatan keilmuan Usul al-Fiqh dengan berbagai cabang ilmu ikutannya (Fikih, Kalam, Tafsir, Hadis), sedang menyebut sains, perubahan sosial, negara-bangsa dan peradaban global melibatkan pengalaman umat manusia (human experiences) pada umumnya. Human experiences melibatkan ruang lingkup cara berpikir manusia secara lebih umum (rationality), metode berpikir ilmu pengetahuan (method and approach)) serta nilai-nilai baru (values) yang muncul akibat perjumpaan antara ketiganya. ${ }^{30}$

Para pemikir, penulis dan peneliti Muslim kontemporer -dalam kadar yang berbeda-beda- mempunyai kemampuan untuk mendialogkan dan mempertautkan antara paradigma 'Ulum al-din (Ilmu-ilmu agama Islam), alFikr al-Islamy (Pemikiran Keislaman) dan Dirasat Islamiyyah (Studi Keislaman) kontemporer dengan baik. Yakni, 'Ulum al din (Kalam, Fiqh, Tafsir, 'Ulum alQur'an, Hadis) atau ilmu agama Islam yang dipertemukan dan didialogkan dengan sungguh-sungguh, diintegrasikan dan diinterkoneksikan - dengan Dirasat Islamiyyah (Islamic Studies) dengan mempertimbangkan masukan dan menggunakan cara berpikir dan metode sains modern, social sciences dan humanities kontemporer sebagai pisau analisis dan cara berpikir keagamaannya. ${ }^{31}$ Dalam studi Islam kontemporer, mereka tidak lagi menggunakan model linearitas bidang ilmu yang ditonjolkan, tetapi studi figh, kalam atau tafsir yang diintegrasikan dan diinterkoneksikan dengan disiplin keilmuan alam (biologi, psikologi, kesehatan, kedokteran dan lainnya), social sciences, seperti sejarah, sosiologi, antropologi serta humanities kontemporer serta metode sains pada umumnya. Muhammad Almistiry menggunakan istilah al-tamazuj al-ma'rify baina mukhtalafi al-takhassusat (percampuran ilmu pengetahuan antar berbagai spesialisasi atau keahlian yang berbeda-beda); al-muqarabah al-takamuliyyah li alma'rifah (pendekatan keilmuan yang saling melengkapi antar berbagai disiplin ilmu); juga ushul murakkabah muta'adidatu al-takhassus (fundasi ilmu yang berlapis terdiri dari berbagai disiplin atau spesialisasi ilmu). ${ }^{32}$

30. Bandingkan dengan Jasser Auda, Op. cit., h. 155-6; 160.

31. Saya telah mengelaborasi hubungan antara ketiga cluster keilmuan Islam, yaitu antara Ulum al-Din, alFikr al-Islamy dan Diirasat Islamiyyah dalam tulisan "Mempertautkan Ulum al-Din, Al-Fikr al-Islamy dan Dirasat al-Isalimyyah: Sumbangan Keilmuan Islam untuk Peradaban Global" dalam Marwan Saridjo (Ed), Mereka Bicara Pendidikan Islam: Sebuah Bunga Rampai, (Jakarta: PT Raja Grafindo Persada, 2009), h.261298.

32. Muhammad Almistiry, Jadalu al-ta'shil wa al-mu'asarah fi al-fikr al-Islamy, (Tunisia: Mansyurat karim alsyarif, 2014), h.17; 28. 


\section{Pengembangan Metode Studi Ilmu-ilmu Keislaman}

Abdullah Saeed, sebagai contoh adalah cendekiawan Muslim yang berlatar belakang pendidikan bahasa dan sastra Arab serta studi Timur Tengah. Kombinasi institusi pendidikan yang diikuti, yaitu pendidikan di Saudi Arabia dan karir akademik di Melbourne Australia menjadikannya kompeten untuk menilai dunia Barat dan Timur secara proporsional. Saeed sangat konsen dengan dunia Islam kontemporer. Pada dirinya ada spirit bagaimana ajaranajaran Islam itu bisa juga shalih li kulli zaman wa makan (bisa berlaku di segala tempat dan waktu) tetapi dalam konteks kehidupan komunitas Muslim sebagai minoritas yang tinggal di negara-negara Barat. Spirit semacam inilah yang ia sebut sebagai Islam Progressif. Subjeknya disebut Muslim progressif. Islam progressif adalah merupakan upaya untuk mengaktifkan kembali dimensi progressifitas Islam melalui fresh ijtihad yang dalam kurun waktu yang cukup lama telah mati suri ditindas oleh dominasi teks. Dominasi teks ini oleh Mohammad Abid al-Jabiry disebut sebagai dominasi corak epistemologi nalar Bayani dalam pemikiran Islam. Epistemologi Bayani mengedepankan otoritas bahasa (sulthah al-lafdz) atau bahasa (Arab), otoritas asal atau salaf (sulthah al-asl) dan otoritas keserbabolehan (sulthah al-tajwiz), tanpa ada upaya keras melalui penelitian yang berkelanjutan untuk mencari hukum kausalitas keilmuan menjadi budaya dalam hidup kesehariannya. ${ }^{33}$ Metode berpikir yang digunakan oleh Muslim progressif inilah yang disebutnya dengan istilah progressif-ijtihadi. Sebelum dipaparkan bagaimana kerangka dan pola pikir keagamaan Islam yang bercorak Progressif-Ijtihadi ini, ada baiknya dilihat posisi Muslim progressif dalam trend pemikiran Islam yang ada saat ini.

Menurut Saeed, ada enam kelompok pemikiran Muslim era sekarang, yang corak pemikiran keagamaan atau pemikiran Kalam atau teologi berikut epistemologinya berbeda-beda (1) The Legalist-traditionalist, yaitu pemikiran keagamaan atau Kalam yang titik tekannya ada pada hukum-hukum yang ditafsirkan dan dikembangkan oleh para ulama periode pra Modern; (2) The Theological Puritans, yang fokus pemikiran keagamaannya adalah pada dimensi etika dan doktrin Islam yang bercorak puritan; (3) The Political Islamist, yang kecenderungan pemikirannya adalah pada aspek politik Islam dengan tujuan akhir mendirikan negara Islam; (4) The Islamist Extremists, yang memiliki kecenderungan menggunakan kekerasan untuk melawan setiap individu dan kelompok yang dianggapnya sebagai lawan, baik Muslim ataupun non-Muslim; (5) The Secular Muslims, yang beranggapan bahwa agama merupakan urusan

33. Mohammad Abid al-Jabiry, Bunyah al-aql al-araby, Op.cit., h. 560-1; 564. 
pribadi (private matter); dan (6) The Progressive Ijtihadists, yaitu para pemikir modern atas agama yang berupaya menafsir ulang ajaran agama agar dapat menjawab kebutuhan masyarakat modern. Pada kategori yang terakhir inilah posisi Muslim progressif berada. ${ }^{34}$

Karakteristik pemikiran keagamaan, Kalam atau teologi Muslim ProgressifIjtihadis, dijelaskan oleh Saeed dalam bukunya Islamic Thought antara lain adalah sebagai berikut : (1) mereka mengadopsi pandangan bahwa beberapa bidang hukum Islam tradisional memerlukan perubahan dan reformasi substansial dalam rangka menyesuaikan dengan kebutuhan masyarakat Muslim saat ini; (2) mereka cenderung mendukung perlunya fresh ijtihad dan metodologi baru dalam ijtihad untuk menjawab permasalahan-permasalahan kontemporer; (3) beberapa di antara mereka juga mengkombinasikan kesarjanaan Islam tradisional dengan pemikiran dan pendidikan Barat modern; (4) mereka secara teguh berkeyakinan bahwa perubahan sosial, baik pada ranah intelektual, moral, hukum, ekonomi atau teknologi, harus direfleksikan dalam hukum Islam; (5) mereka tidak mengikutkan dirinya pada dogmatism atau mazhab hukum dan teologi tertentu dalam pendekatan kajiannya; dan (6) mereka meletakkan titik tekan pemikirannya pada keadilan sosial, keadilan gender, HAM, dan relasi yang harmonis antara Muslim dan non-Muslim. ${ }^{35}$ Dalam situasi dunia dan negara mewajibkan warga secara keseluruhan untuk menghindari dan mencegah penyebaran wabah pandemi virus korona, di mana bantuan sains kedokteran, farmasi, kesehatan dan keperawatan serta ilmu-ilmu sosial dan humaniora sangat diperlukan, maka memprioritaskan corak berpikir dan beragama progressif dengan semangat solidaritas kemanusiaan dan gotong royong adalah sangat diperlukan dan menjadi prioritas.

34. Abdullah Saeed, Islamic Thought: An Introduction (London and New York: Routledge, 2006). h. 14250. Untuk lebih detil, dapat juga dibaca Omit Safi (Ed.), Progressive Muslims: On Justice, Gender and Pluralism (Oxford, Oneworld Publications, 2003). Tariq Ramadan juga menengarai ada 6 kecenderungan pemikiran Islam abad akhir abad ke-20 dan abad ke-21, yaitu Scholastic Traditionalism, Salafi Literalism, Salafi Reformism, Political Literalist Salafism, Liberal or Rational Reformism, dan Sufism. Lebih lanjut Tariq Ramadan, Western Muslims and the Future of Islam (New York: Oxford University Press, 2004), h. 24-28. Kategorisasi dan klasifikasi trend pemikiran Islam oleh Saeed dan Tariq Ramadan ini memang berbeda dari yang biasa dikenal di tanah air tahun 80 -an, ketika para ilmuwan lebih menekankan pada perbedaan antara Traditionalism dan Modernism, yang kemudian muncul dalam nama mata kuliah seperti Aliran Modern dalam Islam (Modern Trend in Islam).

35. Abdullah Saeed, Islamic Thought., h. 150-1. Bandingkan dengan pandangan Ibrahim M. Abu-Rabi' yang mengkritik model pendidikan Islam Tradisional dan Literalist era sekarang yang masih mem-bid'ah-kan kajian ilmu-ilmu sosial (sociology; anthropology) dan filsafat kritis (Critical Philosophy) dalam pendidikan Islam pada level apapun. "......The discipline of the sociology of religion is looked upon as bid'ah, or innovation, that does not convey the real essence of Islam.". Lebih lanjut Ibrahim M. Abu-Rabi', "A Post- September 11 Critical Assessment of Modern Islamic History", dalam lan Markham and Ibrahim M. Abu-Rabi' (Eds.) 11 September: Religious Perspectives on the Causes and Consequences (Oxford: Oneworld Publications, 2002), h. 36. Cetak hitam dari saya. 
Sekilas tampak jelas bahwa corak epistemologi keilmuan pemikiran Islam kontemporer, dalam pandangan Saeed, adalah berbeda dari corak epistemologi keilmuan dan pendidikan Islam tradisional. Bukan agamanya yang berbeda, tetapi metode pemahaman dan penafsiran serta pendekatannya yang berbeda dari yang pernah berlaku dalam sejarah Islam terdahulu. Penggunaan metode kesarjanaan dan epistemologi tradisional masih tetap ada, dimana nass-nass atau teks-teks al-Qur'an menjadi titik sentral berangkatnya, tetapi metode penafsiran dan pendekatannya telah didialogkan, dikawinkan, diintegrasikan dan diinterkoneksikan dengan menggunakan epistemologi baru yang melibatkan masukan dari natural sciences, social sciences dan humanities kontemporer. Pendapat Abdullah Saeed diatas dapat diperbandingkan dengan pendapat Jasser Auda sebagai berikut:

“...The second impact of the proposed condition of a 'competent worldview' is 'opening' the system of Islamic law to advances in natural and social sciences. Judgements about some status quo or 'reality' can no longer be claimed without proper research that is based on sound and 'competent' physical or social sciences methodology. We have seen how issues related to legal capacity, such as 'the sign of death,' 'maximum pregnancy period,' 'age of differentiation,' or 'age of puberty,' were traditionally judged based on 'asking people.' Since 'methods of scientific investigation' are part of one's worldview,'... I would say that 'asking people' cannot be claimed today without some statistical proof! This takes us to the realm of science (natural and social), and defines a mechanism of interaction between Islamic Law and other branches of knowledge." 36

Terjemah bebasnya sebagai berikut. “... Akibat kedua dari syarat yang diusulkan yaitu 'pandangan dunia yang kompeten' adalah perlunya 'membuka' sistem dan cara berpikir hukum Islam dalam hubungannya dengan capaian-capaian dan masukan dari kemajuan ilmu-ilmu alam dan sosial. Pernyataan, pendapat, pandangan keagamaan, keputusan hukum Islam terkait dengan hal-hal yang selama ini dianggap sudah begitu saja adanya (status quo) atau dianggap sebagai 'realitas' biasa tidak lagi dapat dipertahankan seperti adanya tanpa didukung hasil penelitian yang memadai didasarkan diatas landasan metodologi ilmuilmu fisika-kedokteran dan ilmu-ilmu sosial yang benar dan kompeten. Dari dulu kita tahu bagaimana hal-hal yang terkait dengan bidang hukum, seperti 'tanda kematian', 'masa kehamilan', 'masa pubertas', secara tradisional diputuskan atas dasar 'bertanya kepada masyarakat". Oleh karena 'metode penelitian ilmiah' adalah bagian dari pandangan dunia seseorang, sebutlah

36. Jasser Auda, Op. it., h. 203-4. Cetak miring dan cetak hitam dari saya. 
sebagai 'urf baru ... maka saya berpendapat bahwa 'bertanya kepada masyarakat' tidak lagi dapat diklaim sebagai benar jika tanpa dibarengi bukti statistik!. Itu artinya, kita sekarang mau tidak mau harus bersedia masuk ke wilayah sains (science), baik ilmu-ilmu kealaman maupun ilmu-ilmu sosial, dan harus berani melangkah masuk ke protokol bagaimana sesungguhnya mekanisme hubungan antara hukum Islam dan seluruh cabang ilmu pengetahuan”.

Abdullah Saeed memang tidak menyebut penggunaaan metode dan pendekatan tersebut secara eksplisit disitu - Jasser Auda lebih tegas menyebutkannya - tetapi pencantuman dan penggunaaan istilah 'pendidikan Barat modern' adalah salah satu indikasi pintu masuk yang dapat mengantarkan para pecinta studi Islam dan pendidikan dan dakwah Islam kontemporer ke arah yang saya maksud. Barat disini bukan berarti wilayah territorial apalagi agama, tetapi lebih pada wilayah pengalaman dan pengembangan keilmuan. Juga isu-isu dan persoalanpersoalan humanitas kontemporer terlihat nyata ketika Saeed menyebut keadilan sosial, lebih-lebih keadilan gender, HAM dan hubungan yang harmonis antara Muslim dan non-Muslim. Persoalan humanities kontemporer yang mencuat ke ruang publik tidak akan dapat dipahami, dikunyah dan disimpulkan dengan baik, jika epistemologi keilmuan Islam hanya menggunakan metode dan pendekatan 'Ulum al-din lama. Dalam Epilogue, Bab 12 dari bukunya, Abdullah Saeed menjelaskan pandangan dan telaah kritisnya terhadap 'Ulum al-din dan Ilmu-ilmu Syari'ah (lama), yang terdiri dari hadist, usul al-fiqh dan tafsir jika hanya berhenti dan puas dengan menggunakan metode, cara kerja dan paradigma lama. ${ }^{37}$ Kemudian, dalam hal tafsir, dia mengajukan metode alternatif untuk dapat memahami teks-teks kitab suci sesuai dengan perkembangan dan tuntutan tingkat pendidikan dan literasi umat manusia era sekarang ini. Tampak jelas bahwa Abdullah Saeed meneruskan dan mengembangkan lebih lanjut metode tafsir al-Qur'an, yang lebih bernuansa hermeneutis dari pendahulunya Fazlur Rahman. ${ }^{38}$

Isu-isu sosial dan pendekatan sosial yang biasa dikaji dalam ilmu-ilmu sosial dan isu-isu humanities kontemporer yang dikaji dalam filsafat kritis-transformatif serta pendekatan saintitik dalam ilmu-ilmu kesehatan, kedokteran, pengobatan, farmasi, keperawatan dan masih banyak yang lain melalui kajian dan riset empiris ilmu-ilmu kealaman perlu menjadi ancangan dan acuan baru dalam merumuskan ulang kajian ilmu-ilmu keislaman, lebih-lebih ilmu kalam dan ilmu syari'ah, ilmu figh, ilmu tafsir, ilmu hadis dalam payung besar transformasi

37. Abdullah Saeed. Op.cit. h. 145-149.

38. Abdullah Saeed, ibid. h. 145-154. 
pendidikan dan dakwah Islam di dunia Islam pada umumnya dan di Indonesia khususnya. Isu-isu humanities kontemporer, yang membentuk pola pikir baru keagamaan tidak dapat ditawar-tawar bagi mahasiswa pada tingkat universitas - para calon pemimpin bangsa era multikultural-multireliji-multi bencana di masa depan - baik pada level S1, S2 dan terlebih-lebih lagi S3. Rekonstruksi epistemologi dan pengembangan paradigma keilmuan pendidikan Islam ini juga harus terpantul dan terpantau dalam kurikulum, silabi dan literatur yang digunakan oleh para dosen dan mahasiswa.

\section{Penutup}

Paradigma integrasi-interkoneksi keilmuan (takamul al'ulum wa izdiwaj alma'arif; al-tamazuj al-ma'rify baina mukhtalafi al-takhassusat) adalah niscaya untuk keilmuan agama dimasa sekarang, apalagi masa yang akan datang. Jika tidak, maka implikasi dan konsekwensi akan jauh lebih rumit baik dalam tatanan sosial, budaya, lebih-lebih politik, baik politik lokal, regional, nasional maupun global. Linearitas ilmu agama akan mengantar peserta didik berpandangan myopic dalam melihat realitas hidup bermasyarakat dan beragama yang semakin hari bukannya semakin sederhana tetapi semakin kompleks, sekompleks kehidupan itu sendiri. Bagaimana kaitannya dengan ilmu-ilmu agama? Sungguh jauh lebih kompleks, karena dalam agama ada the idea of sacred, sakral, suci, the idea of qat'iy (tidak boleh diubah-ubah), the idea of qat'iy yang dikaitkan atau dilekatkan dengan pemahaman dan penafsiran subjektif manusia tentang Tuhan (fideistic subjectivism) ${ }^{39}$. Tingkat ketersapaan dan dialog antar bidang ilmu akan jauh lebih sulit, sudah barang tentu. Tapi dengan munculnya para pemikir baru, pemikir yang membawa wawasan baru, upaya untuk merambah jalan yang susah itu semakin terbuka, meskipun perlu kerja yang ekstra keras dan berkesinambungan. Uraian diatas semoga dapat membawa harapan, membuka jalan ke arah dialog dan diskusi yang lebih baik, bukan sekedar berbantahbantahan, berbobot dan lebih produktif untuk menghadapi tantangan kehidupan manusia di masa yang akan datang. Wallahu a'lam bi al-sawab.

39. Bandingkan Abdul-Karim Soroush, "The Evolution and Devolution of Religious Knowledge", dalam Charles Kurzman (Ed.), Liberal Islam: A Sourcebook ( Oxford: Oxford University Press, 1998), h.244-251. Khususnya h.245-6. 


\section{Daftar Pustaka}

Abdullah, M. Amin, “Agama dan Perempuan”, Kompas, 8 Februari 2013. , Islamic Studies di Perguruan Tinggi: Pendekatan Integratif-interkonektif (Yogyakarta: Pustaka Pelajar, 2006).

"Mempertautkan Ulum al-Din, Al-Fikr al-Islamy dan Dirasat al-Isalimyyah: Sumbangan Keilmuan Islam untuk Peradaban Global" dalam Marwan Saridjo (Ed.), Mereka Memperbincangkan Pendidikan Islam: Sebuah Bunga Rampai (Jakarta: Raja Grafindo Press, 2009).

, "Bangunan Baru Epistemologi Keilmuan Studi Hukum Islam dalam Merespon Globalisasi”, Asy-Syir'ah, Vol. 46, No. II, Juli-Desember 2012.

Abu-Rabi', Ibrahim M., "A Post-September 11 Critical Assessment of Modern Islamic History", dalam Ian Markham and Ibrahim M. Abu-Rabi' (Eds.) 11 September: Religious Perspectives on the Causes and Consequences (Oxford: Oneworld Publications, 2002).

Adonis, al-Tsabit wa al-Mutahawwil: Bahts fi al-ibda' wa al-itba' 'inda alarab, London : Dar al-saqi, 2002.

Almistiry, Muhammad, Jadalu al-ta'shil wa al-mu'asarah fi al-fikr al-Islamy, (Tunisia: Mansyurat karim al-syarif, 2014).

Azra, Azyumardi, "Virus Korona; Splinter Agama”, Republika, 2 April 2020.

Barbour, Ian, G., Issues in Science and Religion (New York: Harper Torchbooks, 1966).

...m.n.m. Juru Bicara Tuhan: Antara Sains dan Agama (When Science meets Religion: Enemies, Strangers, or Partners), terjemahan E. R. Muhammad, (Bandung: Penerbit Mizan, 2002).

Bagir, Zaenal Abidin (Et.al.), Laporan Tahunan Kehidupan Beragama di Indonesia tahun 2009 dan 2011, (Center for Religious \& Cross-cultural Studies (CRCS (Sekolah Pascasarjana, Universitas Gadjah Mada, Yogyakarta, 2011).

Boullata, Issa (Ed.), An Anthology of Islamic Studies (Canada: McGill Indonesia IAIN Development Project, 1992).

Cholil, Suhadi (Et.al.), Laporan Tahunan Kehidupan Beragama di Indonesia tahun 2009 dan 2011, (Center for Religious \& Cross-cultural Studies (CRCS (Sekolah Pascasarjana, Universitas Gadjah Mada, Yogyakarta, 2009).

Cox James, L, A Guide to the Phenomenology of Religion: Key Figures, Formative Influences and Subsequent Debates (London: The Continuum International Publishing Group, 2006).

Ess, Josep van, "The Logical Structure of Islamic Theology”, dalam Issa J. Boullata (Ed.), An Anthology of Islamic Studies (Canada: McGill Indonesia IAIN Development Project, 1992). 
Guessoum, Nidlal, Islam's Quantum Question: Reconciling Muslim Tradition and Modern Science (London and New York: I.B. Tauris and Co Ltd., 2011).

Harari, Yuval Noah, Homo Deus: A Brief History of Tomorrow (New York: Harper. Perennial, 2017).

https://www.aljamiah.or.id/index.php/AJIS/article/view/52108 https:// www.google.com/url?sa=t\& source=web\&rct=j\&url=https:// aminabd.files.wordpress.com/10/2013/agama-ilmu-dan-budaya. pdf\&ved=2ahUKEwig8bDPg_PoAhWj8HMBHXxDD2kQFjAAegQIA RAB\&usg=AQvVaw3azoWmM2TvBBLufQWLd4vX

al-Jabiry, Mohammad Abid, Bunyah al-Aql al-Araby: Dirasah tahliliyyah naqdiyyah li nudzumi al-m'rifah fi al-tsaqafah al-arabiyyah (Beirut: al-Markaz al-tsaqafy al-araby, 1993).

Kartodidjo, Sartono, Pendekatan Ilmu Sosial dalam Metodologi Sejarah (Jakarta: Gramedia, 1992).

Kurzman, Charles, (Ed.), Liberal Islam: A Sourcebook (Oxford: Oxford University Press, 1998).

Markham, Ian and Ibrahim M. Abu-Rabi' (Eds.) 11 September: Religious Perspectives on the Causes and Consequences (Oxford: Oneworld Publications, 2002).

Nasr, Hamid Abu Zaid, Naqd al-Khitab al-Diniy (Qahira: Sina li al-nasyr, 1994).

Moosa, Ebrahim, "Perjumpaan Sains dan Yurisprudensi: Pelbagai Pandangan tentang Tubuh dalam Etika Islam Modern", dalam Ted Petters, Muzaffar Iqbal dan Syed Nomanul Haq (Eds.), Tuhan, Alam, Manusia: Perspektif Sains dan Agama, terjemahan Ahsin Muhammad, Gunawan Admiranto dan Munir A. Muin (Bandung: PT Mizan, 2006).

Petters, Ted, Muzaffar Iqbal dan Syed Nomanul Haq (Eds.), Tuhan, Alam, Manusia: Perspektif Sains dan Agama, terjemahan Ahsin Muhammad, Gunawan Admiranto dan Munir A. Muin (Bandung: PT Mizan, 2006).

Abu-Rabi', Ibrahim M., "A Post-September 11 Critical Assessment of Modern Islamic History", dalam Ian Markham and Ibrahim M. Abu-Rabi' (Eds.) 11 September: Religious Perspectives on the Causes and Consequences (Oxford: Oneworld Publications, 2002).

Ramadan, Tariq, Western Muslims and the Future of Islam (New York: Oxford University Press, 2004).

Richard C. Martin (Ed.), Approaches to Islam in Religious Studies, (Tucson: The University of Arizona Press, 1985).

Rolston, III, Holmes, Science and Religion: A Critical Survey (New York: Random House, Inc., 1987).

Sadri, Mahmoud Sadri Ahmad (ed.), Reason, Freedom, and Democracy in Islam: Essential Writings of Abdolkarim Soroush, (Oxford: Oxford University Press, 2000). 
Saeed, Abdullah, Interpreting the Qur'an: Towards a contemporary approach (New York NY: Routledge, 2006).

Islamic Thought: An Introduction (London and New York: Routledge, 2006).

Saridjo Marwan (Ed.), Mereka Bicara Pendidikan Islam: Sebuah Bunga Rampai, (Jakarta: PT Raja Grafindo Persada, 2009).

Safi, Omid, (Ed.), Progressive Muslims: On Justice, Gender and Pluralism Oxford, Oneworld Publications, 2003).

Shahrur, Mohammad, Nahw Usul al-Jadidah li al-Figh al-Islamy: Figh al- Mar'ah (Damaskus, 2000).

Sutaryo dkk, Buku Praktis Penyakit VIRUS CORONA 19 (COVID19-), (Yogyakarta: Gadjah Mada University Press, 2020).

Smart, Ninian. Dimensions of the Sacred: An Anatomy of the World's Beliefs (London: Fontana Press, 1977).

Soroush, Abdul-Karim, "The Evolution and Devolution of Religious Knowlegde" dalam Charles Kurzman (Ed.), Liberal Islam: A Sourcebook (Oxford: Oxford University Press, 1998).

Suyadi, Adrianus, "Peran Agama Hadapi Covid 19-”, Kompas, 26 Maret 2020.

Umam, Zacky Khairul, "Korona, Antara Sains dan Agama”, Kompas, 10 Maret 2020

Priyanto Wibowo dkk., Yang Terlupakan Pandemi Influenza 1918 di Hindia Belanda, Depok: Kerjasama antara Departemen Sejarah Fakultas Ilmu Pengetahuan Budaya, Universitas Indonesia, Unicef Jakarta dan Komnas FBPI, 2009.

Wissema, J.G., Towards the Third Generation University: Managing the University in Transition, UK, Edwards Elgar, 2009. 